\title{
The Labor Force Participation Rate: A Rexamination Of The Determinants Of Its Decline
}

Patrick J. Litzinger, Ph.D., Robert Morris University, USA

John H. Dunn, Jr., MBA, Robert Morris University, USA

\begin{abstract}
The U.S. Labor Force Participation Rate (LFPR) is defined as the number of people in the labor force as a percentage of the civilian noninstitutional population 16 years and over. In a paper published in November, 2013, we examined the determinants of the decline in the LFPR from a 1998 peak of $67.2 \%$ to then, $63.3 \%$. Consensus of a number of economic studies at that time was that the primary determinant of the decline was cyclical, and that an improving economy would stop, if not reverse, the downward trend. Since that time, the unemployment rate has declined from $7.2 \%$ to $5.3 \%$. However, the LFPR has continued its decline to $62.6 \%$. Structural issues in the economy would appear to have far greater effect on LFPR decline than previously believed. In this paper we examine the following classes of structural determinants and their effects on LFPR: demographics, including not only the prime working cohort of ages 25 to 54, but also those of retirement age; the impact of a welfare system that appropriately provides a critical safety net, but one that reduces incentive to work through disability payments, extended unemployment benefits, and other subsidies; education for both those of a higher level of attainment, as well as an underclass that no longer receives training by business, but must rely on both public and private vocational education; and finally the consequences of globalization on the economy, including the virtual disappearance of semi-skilled industries in the United States that heretofore have provided jobs for high school graduates.
\end{abstract}

Keywords: Labor Force Participation Rate; Unemployment Rates; Demographics/Cohorts; Apprenticeships; Technical Education; Welfare; Operant Conditioning; Globalization Industrial Policy

\section{INTRODUCTION}

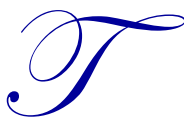

he U. S. Labor Force Participation Rate ("LFPR" or "participation rate") is the number of people in the labor force as a percentage of the civilian noninstitutional population 16 years and over. (U.S. Bureau of Labor Statistics, 2014) As of June, 2015, the labor force in the U. S. was 250.7 million.

The LFPR in the same month fell to 62.6\% -- its lowest level since 1977. The LFPR is based upon the U.S. Bureau of Labor Statistics' U-3 definition of the unemployment rate: "Total unemployed persons, as a percent of the civilian labor force (the official unemployment rate)". (U.S. Bureau of Labor Statistics, 2008) In June 2015, U-3 declined to $5.3 \%$.

The Bureau of Labor Statistics also maintains other measures of labor underutilization. U-4 measures the total unemployed plus discouraged workers, as a percent of the civilian labor force plus discouraged workers. U-5 measures total unemployed, plus discouraged workers, plus all other persons marginally attached to the labor force, as a percent of the civilian labor force plus all persons marginally attached to the labor force. U-6 measures total unemployed, plus all persons marginally attached to the labor force, plus total employed part time for economic reasons, as a percent of the civilian labor force plus all persons marginally attached to the labor force. In June 2015: U-4 was 5.7\%, U-5 was 6.4\%, and U-6 was 10.5\%. (Bureau of Labor Statistics, 2015) 

definitions:

Those alternative measures of labor underutilization depend on the following Bureau of Labor Statistics

- Persons marginally attached to the labor force are those who currently are neither working nor looking for work but indicate that they want and are available for a job and have looked for work sometime in the past 12 months.

- $\quad$ Discouraged workers, a subset of the marginally attached, have given a job-market related reason for not currently looking for work.

- $\quad$ Persons employed part time for economic reasons are those who want and are available for full-time work but have had to settle for a part-time schedule.

(Bureau of Labor Statistics, 2015)

As people move into the marginally attached to the labor force category, the official unemployment rate declines. There is concern over the current decline in LFPR, and there is worry that the decline in the official unemployment rate may cause a false sense of accomplishment.

Litzinger and Dunn (2013) noted an almost steady, month to month, increase in LFPR from 1950 to 2000. There were various structural economic reasons for that increase: better working conditions, a healthier work force, increased participation by minorities and immigrants, and women entering the workforce.

Beginning in 2000, the LFPR began its precipitous decline. That decline was originally viewed simply as part of the general economic decline involved with the recession at the turn of the century and the Great Recession from 2007-2009. If cyclical factors were the only causes of the decline in general economic condition (including the decline in LFPR), it would be expected that the LFPR would be recovering with economic conditions and the official unemployment rate. The continuing decline in LFPR suggests the presence of structural changes. While considering structural changes in the U. S. economy that directly affect the LFPR, it should be noted there are held beliefs concerning those structural changes, that are only partially true.

Chart 1. LFPR vs. Unemployment

The data of the LFPR and the unemployment rates of U3 and U6 during the period from 2000 to 2015

\begin{tabular}{|c|c|c|c}
\hline Year & LFPR & U3 & U6 \\
1998 & $67.2 \%$ & $4.4 \%$ & $7.6 \%$ \\
1999 & $67.1 \%$ & $4.0 \%$ & $7.1 \%$ \\
2000 & $67.0 \%$ & $3.9 \%$ & $6.9 \%$ \\
2001 & $66.7 \%$ & $5.7 \%$ & $9.6 \%$ \\
2002 & $66.3 \%$ & $6.0 \%$ & $9.8 \%$ \\
2003 & $65.9 \%$ & $5.7 \%$ & $9.8 \%$ \\
2004 & $65.9 \%$ & $5.4 \%$ & $9.2 \%$ \\
2005 & $66.0 \%$ & $4.9 \%$ & $8.6 \%$ \\
2006 & $66.4 \%$ & $4.4 \%$ & $7.9 \%$ \\
2007 & $66.0 \%$ & $5.0 \%$ & $8.8 \%$ \\
2008 & $65.8 \%$ & $7.3 \%$ & $13.6 \%$ \\
2009 & $64.6 \%$ & $9.9 \%$ & $17.1 \%$ \\
2010 & $64.3 \%$ & $9.3 \%$ & $16.6 \%$ \\
2011 & $64.0 \%$ & $8.5 \%$ & $15.2 \%$ \\
2012 & $63.7 \%$ & $7.8 \%$ & $14.4 \%$ \\
2013 & $62 \%$ & $13.1 \%$ \\
2014 & $62.8 \%$ & $6.7 \%$ & $11.2 \%$ \\
2015 & $62 \%$ & $5.6 \%$ & $10.5 \%$ \\
\hline
\end{tabular}


Civilian Labor Force Participation Rate

(Percent;16 years and over; seasonally adjusted)

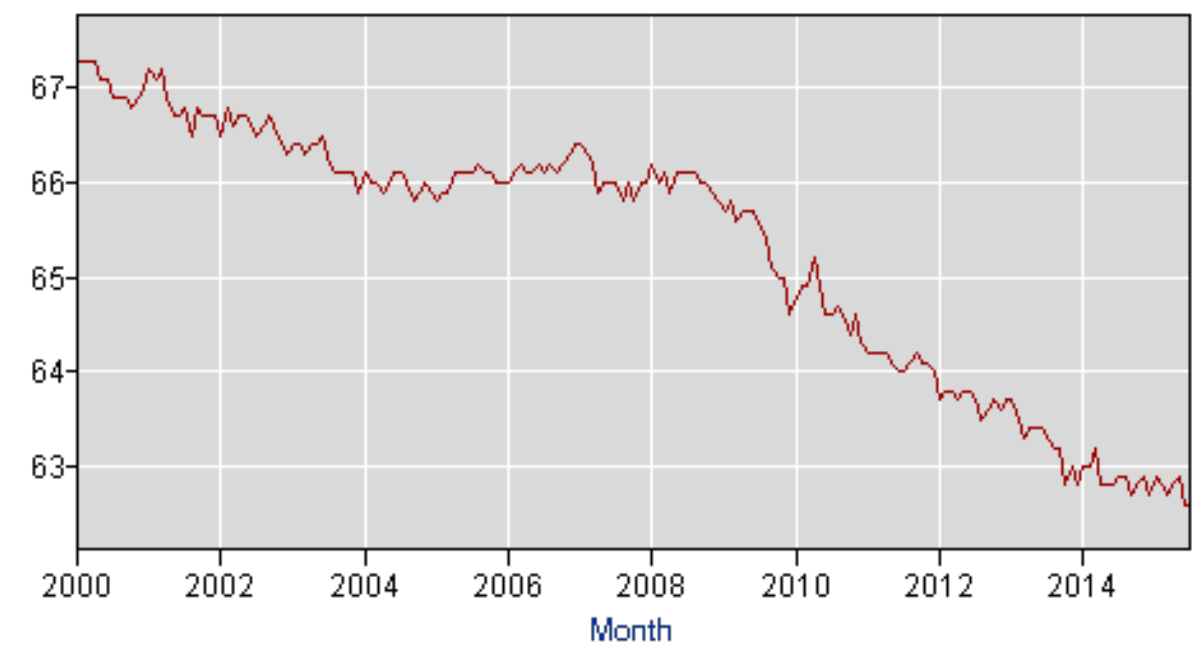

First, among demographic changes, there is the belief the "baby boomers" are retiring, which means that a wave of the population is leaving the labor force. We spend a section examining that view and have found that the decline in the LFPR includes most other cohorts as well, notably the prime working age segment of 25 to 54 . Interestingly, although the baby boomers are decreasing as a per cent of the population, their LFPR is actually increasing. Also many believe that the reduction in the LFPR of the younger cohorts is due to those staying in school longer. While this has some validity, over time those cohorts are reducing their LFPR as well.

Second, jobs in America have become more technical, and the problem will be finding enough educated people to fill those jobs. If America had a greater number of highly educated people, since that segment traditionally has a higher LFPR, education should be one solution to the falling LFPR. We demonstrate that although the higher educated segment does, in fact, have a higher LFPR, since 2000, its LFPR has been falling like the others.

Third, although America's GDP is becoming more globalized, that increased overseas demand will provide sufficient employment and workforce opportunities. Our economy has shifted from manufacturing to a service economy, and productivity increases in manufacturing have meant more production with fewer people. Trade agreements have, or will have, allowed greater growth in the multinational corporations, and they will outsource employment opportunities to the smaller, U.S. based subcontractors. Again although some of these beliefs are true, the fact of the matter is that manufacturing's share of the GDP has been declining steadily since 1950 (Dunn). One could expect that productivity would mean fewer manufacturing employees, but manufacturing, as a percent of GDP, would not necessarily decline as well. It has. Moreover, there are whole classes of semi-skilled manufacturing jobs that have disappeared to other countries, and that leaves the less educated American worker, or his/her immigrant counterpart, with no reason to join or stay in the labor force. We discuss the concept of an Industrial Policy as one solution

Finally, we examine the effects of a generous, but badly structured welfare system. The poor must be provided for, perhaps in even greater amounts than today, but the incentives for work must always be there.

\section{CYCLICALITY}

Our previous paper (Litzinger and Dunn) was published in November of 2013, and was based primarily of data and papers that are now two to three years old. At that time many of the economists that looked at the decline in the Labor Force Participation Rate (LFPR), were convinced that cyclical forces were predominately responsible for that decline. 
Examples abound. In April of 2013, Christopher J. Erceg and Andrew T. Levin concluded: “ ...this shift in the prime-age LFPR was not (italics, theirs) a mere coincidence but instead was caused by the Great Recession and its aftermath; that is prime-age adults dropped out of the labor force as a consequence of a large and persistent shortfall in labor demand (again, italics theirs). They add: "1) decreases in labor force participation appear relatively modest in most post-war recessions, but 2) protracted recessions may eventually induce large declines in participation. Our model implies that labor force participation responds inversely to the unemployment rate..." (Erceg and Levin). Empirically, our chart in the previous Introductory section belies this conclusion. From the end of the Great Recession in 2009 to June, 2015 the unemployment rate (U3) has fallen from 9.9\% to 5.3\%, and the U6 , from $17.1 \%$ to $10.5 \%$, while the LFPR continued to plummet from $64.6 \%$ to $62.6 \%$. The authors conclude: "Quite intuitively, keeping unemployment persistently low draws cyclical non-participants back into more quickly." (Erceg and Levin) That hasn't happened.

Heidi Shierholz in March, 2012 concluded similarly about the decline in the LFPR: "it has kept unemployment lower than it otherwise would have been, since most of the decline was due to people dropping out of (or not reentering) the labor force because of weak job prospects. However, when job prospects pick up substantially and these sidelined workers start entering or reentering the labor market as job seekers, they will keep the unemployment rate from coming down (italic hers) as fast as it otherwise would have been." The opposite has occurred: unemployment has fallen as the LFPR has experienced a decline.

Julie L. Hotchkiss and Fernando Rios-Avila came to similar conclusions as Erceg and Levin and Shierholz . In March of 2013, describing the past Great Recession: "We find that over this time period, deteriorating labor market conditions explain more than the entire drop (italics, ours) in observed LFPR ...". They add: “...an economic recession is theorized to directly reduce the incentive to participate in the labor market (i.e. with lower employment opportunities, the expected wage may fall below a person's reservation wage, reducing the likelihood of participating in the labor force)." (Hotchkiss and Rios-Avila) While these authors focus on a worker leaving the labor force because of too low a wage, in our section on Globalization, we see the same attitude shift coming from the loss of semi-skilled manufacturing jobs, where potential workers give up hope because there just aren't any jobs available for their skill levels.

Finally, Edward P. Lazear and James R. Spietzer, conclude: "An analysis of labor market data suggests that there are no structural changes that can explain movements in unemployment rates over recent years. Neither industrial nor demographic shifts nor a mismatch of skills with job vacancies is behind the increased rates of unemployment." (Lazear and Spietzer). And as Lazear wrote in the Wall Street Journal, “...the problems in the labor market are not structural. They reflect slow economic growth, and the cure is a decent recovery". (Lazear WSJ).

As we discussed in our prior paper, Lazear and Spietzer left the door open for structural causes in their analysis of the Beveridge Curve. As they said," Movements along the Beveridge Curve are interpreted as cyclical in labor demand, whereas shifts in the Beveridge curve up and to the right are typically interpreted as structural shifts in unemployment, reflecting a reduced efficiency in matching workers to jobs. The apparent outward shift in the Beveridge curve and the resulting increase in unemployment may be consistent with a structural change that occurred after June 2009, but it is equally consistent with the counter clockwise dynamics observed in previous recessions and recoveries. ... Whether this apparent shift in the Beveridge curve is a permanent change cannot be known until employment returns to normal levels." (Lazear and Spietzer)

In our previous paper we included a graph of the Beveridge curve as of April 2013. As of April 2015, the shift in the curve is much more pronounced, even as the rate of unemployment returned close to prerecession or "normal" levels. 


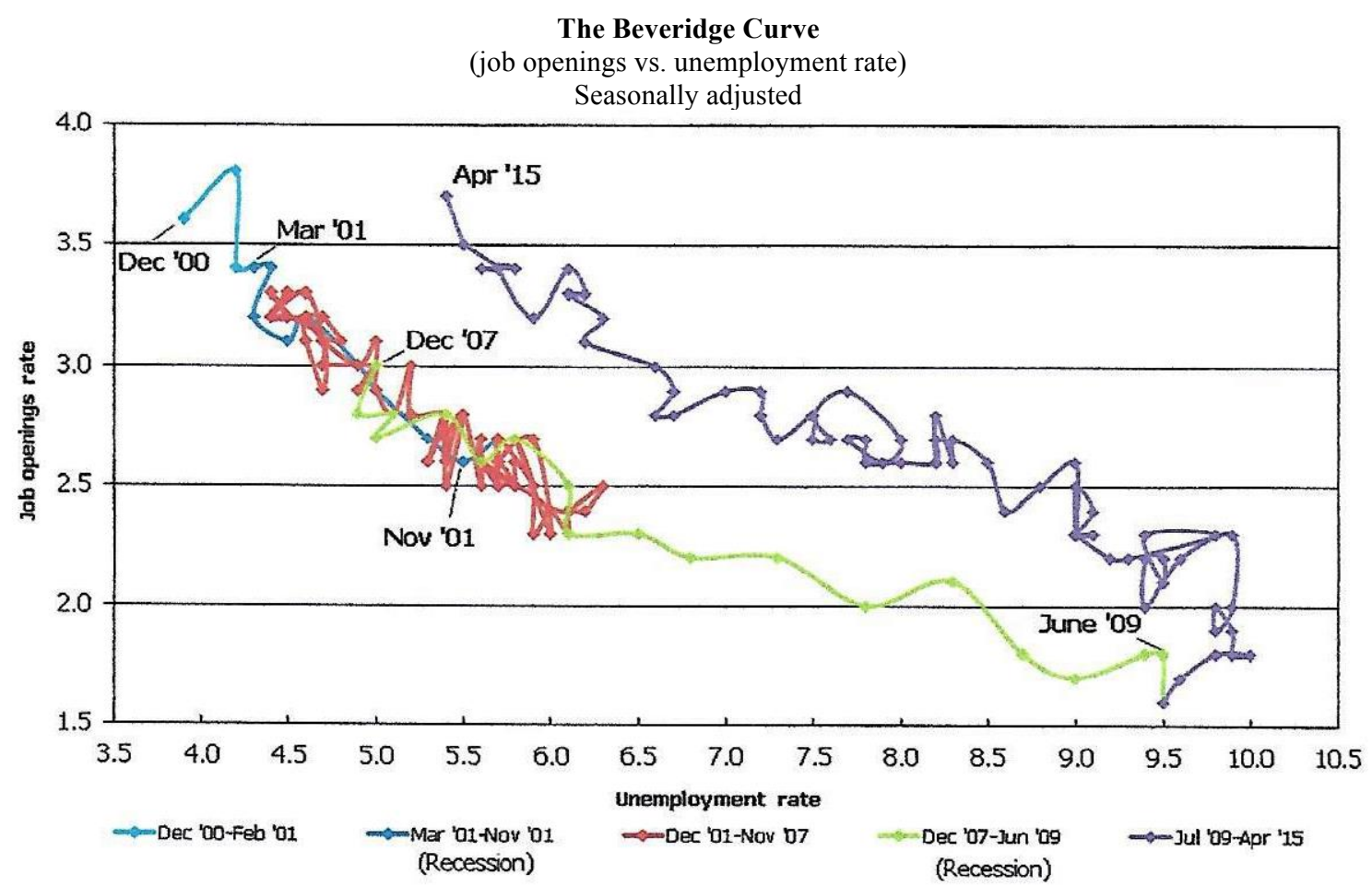

Source: Bureau of Labor Statistics, Current Population Survey and Job Openings and Labor Turnover Survey, June 9, 2015.

- This graph plots the job openings rate against the unemployment rate. This graphical representation is known as the Beveridge Curve, named after the British economist William Henry Beveridge (1879-1963). The economy's position on the downward sloping Beveridge Curve reflects the state of the business cycle.

- During an expansion, the unemployment rate is low and the job openings rate is high. Conversely, during a contraction, the unemployment rate is high and the job openings rate is low. The position of the curve is determined by the efficiency of the labor market. For example, a greater mismatch between available jobs and the unemployed in terms of skills or location would cause the curve to shift outward (up and toward the right).

- From the start of the most recent recession in December 2007 through the end of 2009, each month's point on the curve moved lower and further to the right as the job openings rate declined and the unemployment rate rose. From 2010 to the present, each month's point moved up and to the left as the job openings rate increased and the unemployment rate decreased.

- In April 2015, the job openings rate was 3.7 percent and the unemployment rate was 5.4 percent, which is higher than the unemployment rate before the recent recession for the same level of job openings.

What follows then are the structural causes in the decline in the LFPR: Demographics, Welfare, Education, and Globalization.

\section{DEMOGRAPHICS}

Since our previous publication in October of 2013, there has been a major improvement in the economy, and a resultant reduction of unemployment measures either by U3 or U6. The former, or official, unemployment rate is the proportion of the civilian labor force that is unemployed but actively seeking employment, and has dropped from its recessionary high in 2009 of $10.0 \%$ to the June 2015 of $5.3 \%$. Likewise the U6, which includes the discouraged, the marginally attached, and part time workers, dropped from a high of $17.1 \%$ in April of 2010 to $10.5 \%$. Nonetheless, the Labor Force Participation Rate (LFPR) averaged $65.0 \%$ in the depth of the Great Recession, but instead of climbing back with improved employment, it continued its slide to June 2015 of $62.6 \%$. 
Implicit in these contrasting numbers is the view that although cyclical forces have contributed to the decline, there are structural forces that have a major effect on the LFPR decline. The largest appears to be demographic.

We have found three economic/demographic studies to be particularly significant: The first, Labor Force Participation: Recent Developments and Future Prospects, by Stephanie Aronson, Tomaz Cajner, Bruce Fallick, Felix Galbis-Reig, Christopher L. Smith, and William Wascher (Aronson) The study was largely a revisit of a Brookings paper in 2006. The second, the December 2013 Bureau of Labor Statistics, Monthly Labor Review, "Labor force projections to 2022: the labor force participation rate continues to fall". (BLS) The third, is a poll of the non-employed, conducted by the Kaiser Family Foundation/New York Times/CBS News. The first two studies are quantitative; the third takes a more qualitative approach often not demarking the line between the often long term unemployed and those that have left the labor force. (Kaiser).

The results are disturbing, and one can conclude that enhanced Monetary Policy will not have a consequential effect. If we view the structural factors: "To the extent that they are caused by obstacles faced by individuals who would like to work or disincentives to work, policymakers would be well-advised to mitigate them. However, some of the structural factors may be unpreventable (such as the aging of the population) or undesirable to reverse (such as higher school enrollment rates among the young), leading to a slower growth of potential output." (Aronson) That study made three calculations about the post 2007 period, and "all indicate that the changing age distribution of the population has been a substantial component of the decline in aggregate labor force participation over this period, with our preferred calculation attributing nearly half of the observed decline to this source" (Aronson)

At this point it seems appropriate to view the decline as a product of the aging of the baby boomers, and their subsequent retirement. But it is not that easy. First, the decline in the LFPR of other population cohorts must be examined. Secondly, there are other qualitative changes in America such as the impact of welfare and the disappearance of semi-skilled jobs, which will be examined in later sections of this paper. "A separate analysis by Hall (2014) comes to a similar conclusion, but suggests much of the decline beyond that of aging to a combination of an increase in disability recipients and the expansion of the food stamp program, both of which discourage participation by implicitly taxing earnings" (Aronson) And although we will discuss these forces in greater detail, there is nothing quantifiable beyond the demographic issues.

They examine the key demographic cohort: ages $25-54$. One can see that the problem is not just retirees. In the Kaiser poll, "Americans ages 25-54 who are not currently working (a group we will refer to throughout this report as 'the non-employed' make up 13\% of the entire U.S. adult population. Among this group, about a third (34 percent) say they have a disability that prevents them form doing any kind of work for at least the next six months. The remainder say they are able to work, including about a quarter each who consider themselves unemployed (24 percent) and homemakers ( 26 percent), 10 percent who call themselves students and 4 percent who say they are retired." (Kaiser) The poll mixes unemployed with out of the labor force, but of the $25-54$ cohort, $13 \%$ are non employed, and of those, about $25 \%$ are unemployed. Interpolating, the LFPR for the 25-54 cohort, the LFPR is reduced by $3.25 \%$ for structural causes. Or put another way by the same poll: "For men, the decline has been occurring since the 1990s, when only about 5 percent of those between the ages of 25 and 54 did not work. Today, 16 percent of these men, supposedly in the prime working years of their lives, do not work. For women, the decline of work is more recent and more modest, dating only to 2000." (Kaiser/NY Times) Thus, "the aging of the population accounts for some of the decline, but it cannot explain why participation among prime age workers between 25 and 54 stands only at $81 \%$, more than 2 points below its level in 2007 before the recession, (Gaston, WSJ)

Aaronson concludes: "In particular, participation rates among youths have been declining since the mid1990s, in part reflecting the higher returns to education documented extensively by other researchers, but we also believe, some crowding out of lob opportunities for young workers associated with middle-skill jobs and thus greater competition for the low-skilled jobs traditionally held by teenagers and young adults" (The lack of jobs available to the person who lacks a college degree will be examined in the Globalization section. Much of the semiskilled industries in America have moved off-shore, and with them job opportunities for high school graduates). 
In the 19-24 age cohort, part of the LFPR decline is explained by the rising enrollment in educational institutions. The Monthly Labor Review of December 2013 by the Bureau of Labor Statistics, is entitled: "Labor force projections to 2022; the labor force participation rate continues to fall." (BLS)

This chart sums up their projections.

\begin{tabular}{l|cccc}
\hline \multirow{2}{*}{ Group } & \multicolumn{4}{c}{ Participation Rate in \% } \\
\cline { 2 - 5 } & $\mathbf{1 9 9 2}$ & $\mathbf{2 0 0 2}$ & $\mathbf{2 0 1 2}$ & $\mathbf{2 0 2 2}$ \\
\hline Total, 16 years and older & 66.4 & 66.6 & 63.7 & 61.6 \\
Ages 16 to 24 & 66.1 & 63.3 & 54.9 & 49.6 \\
Ages 25 to 64 & 83.6 & 83.3 & 81.4 & 81.0 \\
Ages 65 and older & 11.5 & 13.2 & 18.5 & 23.0 \\
\hline
\end{tabular}

Just looking at the participation rate percentages draws some preliminary conclusions. Yes, the overall participation rate is expected to decline for reasons mentioned above. More serious, however, is that the prime age workers, ages 25-54, declines significantly and this is the group about which we need to worry. Interestingly, the retirement age participation rate gets elevated, for reasons that include less reliance on pensions, living healthier, greater longevity, all of which contribute to the need to continue to work.

But until you look at the population in total, these percentages lack real meaning. However, the BLS has good statistics on the percentage of the population that each of these selected cohorts represents:

\begin{tabular}{l|cccc}
\hline \multirow{2}{*}{ Group } & \multicolumn{4}{|c}{ Participation Distribution } \\
\cline { 2 - 5 } & $\mathbf{1 9 9 2}$ & $\mathbf{2 0 0 2}$ & $\mathbf{2 0 1 2}$ & $\mathbf{2 0 2 2}$ \\
\hline Ages 16 to 24 & 16.9 & 15.4 & 13.7 & 11.3 \\
Ages 25 to 64 & 71.4 & 70.2 & 65.3 & 63.1 \\
Ages 65 and older & 11.8 & 14.3 & 20.9 & 25.6 \\
\hline
\end{tabular}

For women: "The overall participation rate for women began increasing toward the end of the 1940s, accelerated in the 70s, and continued rising until 1999, when it peaked at 60.6 percent. Since then, the aggregate labor force participation rate of women, which historically compensated for the decline in the aggregate labor force participation rate, also has been decreasing and is now contributing to the decline in the aggregate labor force participation rate.... The women's participation rate is expected to continue to decline ... and drop to 56.0 percent in 2022. (BLS)

In summary, the aggregate demographics are exacerbated: not only in the LFPR drop for all cohorts, except those retired or close it, but all other groups have a population decrease in terms of the percentage of the U.S., and their LFPR declines as well. So the problem is not just the aging of the so called baby boomers population to retirement, but the participation rate for the rest of America declines as well. We will explore some of the other reasons for the decline in the rest of the paper.

\section{EDUCATION}

The common wisdom is that a better educated labor force will have more employment opportunities, and with those opportunities should come increases in the LFPR. As America's jobs becomes more technical and needs for an educated labor force increase, the Labor Force Participation Rate should improve as a function of education. Part of this is true: the higher the attained level of education, the higher the LFPR. But the same secular forces, about which we have written, still prevail among each group. For each achieved educational level the decline in the LFPR continues. In looking again at demographics, declines in the LFPR in certain age cohorts are partially explained by leaving the labor force for school. But that appears in only two age cohorts. Finally the lack of training programs/ apprenticeships has hurt the undereducated group, but this is inexorably linked to the decline in manufacturing as discussed in the prior section. 
There is a great deal of data from the Bureau of Labor Statistics, such as:

\begin{tabular}{lcc}
\hline \multicolumn{3}{c}{ Select LFPRs for Level of Educational Attainment } \\
\hline \multicolumn{1}{c}{ Educational level } & LFPR 2000 (\%) & FPR 2015 (\%) \\
\hline Less than high school & 43.5 & 45.2 \\
High school graduate & 64.4 & 56.9 \\
Some college & 73.9 & 66.9 \\
Bachelors degree and higher & 79.4 & 74.1 \\
\hline
\end{tabular}

As one can readily see, the higher the educational level, the higher the LFPR. But equally glaring is the continuous decline since 2000. The Great Recession effectively ended in 2009, but the downward trend continued unabated. (BLS, Education)

Certain cohorts are affected by people dropping out of the labor force to stay in, or return to school. Of those not in the labor force in 2007, 17.8\% of the less than high school segment can be explained by being in school. That figure rose to $21.7 \%$ by 2013. (this explains the seeming anomaly in the above chart). The same was true for the some college segment: $6.2 \%$ in 2007 and $7.2 \%$ in 2013. But for the rest of the segments, especially the high school graduates, not being in the labor force was not due primarily to being in school. (Sherk). One hope in this demography is that historically the retired have less education than younger people, so one could expect some increase in the LFPR just because America will have a better educated population. (Spreen).

Generally speaking, American companies appear to be less likely to offer prospective employees training programs, although the statistical data is not available. This has been mitigated somewhat by the certificate programs by both public education, an example being the Community College of Allegheny County, and the private sector, in the Pittsburgh Technical Institute. Those organizations still offer the Associate degree, but alternatively, one can achieve a certificate in subjects like welding, in a more condensed period of time. These institutions often have an advisory board comprised of representatives from local industries, which help ensure that the certificates reflect current employment needs. Unfortunately, for some of those high school students that do not plan to continue with their education, parents/society seems to pressure those students to continue to go to college, reflecting a prejudice against the skilled blue collar employee. This is unfortunate since highly skilled blue collar jobs often pay more that the college graduate without a college major that leads to employment. (Interviews by the author).

In the prior section on the effects of Globalization, a significant comparison was made between the U.S. and Germany in both manufacturing and an industrial policy. "Long regarded by parents, students and many educators as an off ramp from the college track, apprenticeships are getting a fresh look in many quarters." (Schwartz) Speaking of the success of such programs, "'We know this works', said Thomas Perez, the labor secretary, describing how big companies have long trained young people in Germany, which has 40 apprenticeships per 1000 workers, compared to about three per 1000 in the United States. 'It's not hard to figure out why the Germans have a youth unemployment rate that is half of what it is here.' "(Schwartz) Unfortunately, the success of these programs are linked to the Industrial Policy of Germany which has maintained its preeminence in manufacturing. In the U.S. such programs have been hurt by the decline in manufacturing, which was particularly hurt hard in the Great Recession. As was stated before, a less educated youth will leave the labor force, if he/she feels that there are no jobs available.

\section{WELFARE: LEAVING THE LABOR FORCE}

In discussing this topic, the most important premise is that the poor must be helped, not just for the moral aspects, but that the future of free market capitalism depends upon an underclass that is not excluded from the system. But secondly, the needed support for the poor must be structured so that the ability to work, and the dignity that comes with work, must not be extinguished by a system created with little thought to its consequences. One does not reduce desperately needed aid to cause work to be done, but rather any additional work should always produce positive incremental income. 
There is an aspect of behavioral economics that deals with human activity as a function of rewards or, more technically put: reinforcement schedules. B.F. Skinner, the father of modern psychology as a predictive social science, codified operant conditioning as the use of reinforcement to change behavior: "In operant conditioning we "strengthen" the operant" (a class of responses) "in the sense of making a response more probable or, in actual fact, more frequent". (Skinner) In effect, a range of behavior is "conditioned" by the reinforcement provided.

An easy example of this is a heavily trafficked avenue, with a posted $25 \mathrm{mph}$ speed limit, and with sequential traffic lights set at $40 \mathrm{mph}$. The traffic lights reinforce $40 \mathrm{mph}$, which is the speed of most drivers. If you want law abiding citizens, set the lights for $25 \mathrm{mph}$.

The importance of operant conditioning is that most of the welfare programs in the U.S. engender a certain behavioral response. The aim is to help the poor, not keep them poor. But most of the programs, given that they are means tested, result in the fact that work often provides less income to the poor than a working job. In our previous paper we quoted the former Pennsylvania Secretary of Public Welfare, Gary Alexander, He dealt with the "welfare cliff", as "Many Americans either know this intuitively or possess personal experience with the system. The phenomenon is often called the welfare cliff effect. If a typical single mother on welfare earns just a little bit more income, or if she marries a man with a job, the household stands to lose far more in benefits than what the marginal income is worth." (Alexander).

No where has this been more obvious that President Lyndon Johnson's Economic Opportunity Act of 1964, or simply put, the War on Poverty. The view was that enough money would solve poverty. In some respects it worked. From the year the Act was implemented to 1971 , poverty rates dropped form $17.3 \%$ to $11.1 \%$. However, since that time, rates have remained in a bracket of $11 \%$ to $15.2 \%$ since. Through Social Security, the largest drop in poverty has been for those over 65.(War on Poverty)

Intuitively, we know that Alexander's welfare cliff is omnipresent. The means tested premise of the welfare program for the inner city poor, was to create fatherless families. If a working father were present, income would decline. So we were left with fewer male role models for the children in that household. You can ask the first ten people in the phone book, what would happen to the nuclear family with this type of structure, or reinforcement schedule. Despite the good intentions, because no legislator or program director considered the psychological effect of the family, or the sociological implications of children without role models, the result was failure. Although it is impossible to measure directly, would not America have been better off not reducing benefits, allowing for a two income approach to entering the middle class, than penalizing the family? Consider the riots in Watts and Newark then (and more to come later), and the reduced opportunities for the children in the inner cities. Would not much of the cost of keeping the working family together pale in comparison to the resultant anomie?

A good statistical profile of households led by a single woman has been charted by the Census Bureau:

\begin{tabular}{|c|c|c|c|}
\hline Year & Family Households & Female Householder & $\%$ \\
\hline 2014 & 81.4 million & 15.4 million & 18.95 \\
\hline 2010 & 78.3 million & 14.8 million & 18.83 \\
\hline 2000 & 55.3 million & 12.7 million & 17.61 \\
\hline 1990 & 66.1 million & 10.9 million & 16.48 \\
\hline 1980 & 59.6 million & 8.7 million & 14.61 \\
\hline 1970 & 51.5 million & 5.5 million & 10.89 \\
\hline 1960 & 44.9 million & 4.4 million & 9.85 \\
\hline 1950 & 38.8 million & 3.6 million & 9.25 \\
\hline 1940 & 31.5 million & 3.4 million & 10.83 \\
\hline
\end{tabular}

The increased percentage of female householders (one member of the family is related to dependents, without a spouse present) is palpable and very significant. The reinforcement schedule is obvious: Not working is reinforced, as is the exclusion of the male worker. Skinner would say that the behavior for a nuclear family has been extinguished. And in a study of Single Parent Households: “...it was confirmed that single parent households show a negative association of work with well-being, at least compared with other households". (Bauman) 
In our previous paper, we examined Social Security Disability Insurance, SSDI, and quoted from David Autor's paper on the subject. (Autor). The number of in SSDI recipients is increasing (despite OSHA and a more safety conscious America) nearly doubling to about 3.3\% in 2014 from 1975. “...the available evidence suggests that these increases (in retirements and disability) are primarily continuations of longer-term trends and so have largely been driven by structural influences".(Aronson et al.)

The major exception to the above welfare paradigms, is the Earned Income Tax Credit (EITC). "The EITC is a refundable Federal income tax credit for low income working individuals and families. A refundable allows eligible tax payers to reduce or offset their federal tax liability, and receive any remaining credit beyond their tax bill as a refund.... The EITC was authorized in 1975 by Congress to provide incentives to work. " (Basel)

Finally in a paper by the National Bureau of Economic Research, its author examined the decline in the LFPR and stated that "an important part (of the decline) may be related to the large growth in beneficiaries of disability and food-stamp programs. ...Both programs place high taxes on earnings and so discourage labor-force participation among beneficiaries." (Hall)

\section{GLOBALIZATION, UNEMPLOYMENT, AND THE LFPR}

In a prior paper, we discussed the decline of American manufacturing as a percentage of our Gross Domestic Product, and as a per cent of the workforce engaged in manufacturing. This has been largely due to the export of jobs through trade policy. We felt that the declines were a major contributor to the increasing inequality of incomes in the U.S., since manufacturing jobs pay more than service employment. And probably some form of an Industrial Policy would be involved in its remediation. (Dunn)

In this section of our paper, we again examine the decline of manufacturing in terms of output and employment, dealing with the common held belief that part of the decline in employment is due to higher levels of productivity and automation. As a subset of manufacturing, we look at the near disappearance of semi-skilled jobs which are important for two compelling reasons: First, as diverse as America is, and as a magnet for immigration, we need a block of manufacturing jobs for those with minimal skills. Secondly, there will always be a population sector where a high school diploma (or less) is the maximum educational level attained, and there need to be manufacturing jobs available, both for employment and for the ability to use a semi-skilled job as implicit training for ones with a higher skill level. Finally, we look at the trade policy, as typified by the Trans Pacific Partnership (TPP) Trade Act; levels of Gross Private Investment, e.g. capital expenditures with regard to employment; and the exacerbating effects of America's corporate tax policy. While all of these topics have been, and are deserving of separate studies, we will deal with their impact on the declining LFPR. The bottom line: without a decent paying job opportunity, the probability of giving up and leaving the labor force looms large.

Perhaps the best and most comprehensive discussion on this topic is by Nobel Laureate, Michael Spence, in a 2011 article in Foreign Affairs, "Globalization and Unemployment": "But the structural evolution of the global economy today and its effects on the U.S. economy mean that, for the first time, growth and employment in the United States are starting to diverge... At the same time, many job opportunities in the United States are shifting away from the sectors that are experiencing the most growth to those that are experiencing less. The result is growing disparities in income and employment across the U.S. economy, with highly educated workers enjoying more opportunities and workers with less education facing declining employment prospects and stagnant incomes."(Spence)

Spence divides the economy into two sectors: tradable and nontradable. The former is "the sector that produces goods and services that can be consumed anywhere, such as manufactured products, engineering, and consulting services." (Spence) The nontradable sector "produces goods and services that must be consumed domestically." Examples of the latter include, governments, healthcare, retail, construction, and hotel and restaurant industries. Between 1990 and 2008, ten million new jobs were created in the nontradable sector; 600,000 new jobs, for the tradable sector for the same period. The nontradable sector is not likely to generate much growth in jobs and only modest value added per employee. Conversely, the tradable sector has seen large value added per employee, but Spence points out that employment growth there has been limited. Moreover manufacturing's lower valued 
added components have moved offshore, while high end manufacturing and other parts of this sector, like finance and engineering, have experienced growing employment. He concludes: "If the nontradable sector continues to lose its capacity to assure labor, as it has in recent years, and the tradable sector does not become an employment engine, the United States should brace itself for a long period of unemployment." (Spence) That was four years ago and while the rates of unemployment (both U3 and U6) have declined, the employment results, which Spence probably expected, have been in the declining LFPR.

The trade acts, especially NAFTA and the forthcoming TPP, essentially reflect an industrial policy that chooses winners and losers, with the multinationals, e.g. Microsoft and Boeing, and agribusiness in general being the winners. The losers, as examined below, are the semiskilled industries, an even skilled manufacturing like steel. The TPP promises that environmental, labor, and intellectual property regulations will be upheld, but with little governmental agency actions to police not unexpected future violations. And there will be almost no control over currency manipulation. "USW President Leo Gerard believes part of the problem is that the U.S. lacks a comprehensive industrial policy that acknowledges the importance of manufacturing. All we have to fall back on, Mr. Gerard told members of the House Steel Caucus in March, are "trade laws built on an injury test that requires massive bloodletting before any relief is available"' (Boselovic). Gerard should know; only two of the top 50 worldwide steel producers are American.

Part of the problem in manufacturing is held to be that through automation, America produces more with fewer people. Part of this is true, as in the Manufacturing statistics below:

\begin{tabular}{|c|c|c|c|c|}
\hline Year & Gross Output & \% Yearly Change & Employment & \%Yearly Change \\
\hline 1997 & $\$ 1,338.2$ Billion & & 13,591 million & \\
\hline & & +4.21 & & -1.23 \\
\hline 2014 & $\$ 6,143.6$ Billion & & 8,568 million & \\
\hline
\end{tabular}

Real GDP grew at a rate of $3.81 \%$ (pre Great Recession). Given the size of the industrial base of the U.S. in 1997, one might have expected a higher growth rate.(BEA GDP)

The real problem lies in the lack of semi skilled jobs. Historically, semi-skilled jobs allow a progression from semi-skilled to skilled. An example with which we are very familiar is in the Carolinas which began the 1950s; one was hired off the farm or from a developing country to work in textiles or apparel, then to chemical production, then to automobile tire manufacturing, to finally, the automotive production, assembly and export. This often took generations, but the semi-skilled job was the entry to an ultimate high paying automotive job. (One motive for the so-called automobile transplants to the U.S. was the expectation of import legislation). But one doesn't go from a job in food service to one in sophisticated manufacturing. Unfortunately, the unemployment rate has increased there lately due to the major decline in those same semi-skilled jobs.

With Textiles and Apparel as a proxy for the semi-skilled jobs, the statistics are startling (BEA GDP):

\begin{tabular}{|c|c|c|c|c|}
\hline Year & Gross Output & \% Yearly Change & Employment & \%Yearly Change \\
\hline 1997 & \$83.9 Billion & & $1,923.7$ thousand & \\
\hline 2014 & \$85.6 Billion & +0.11 & 8281.7 thousand & -5.06 \\
\hline
\end{tabular}

As we will discuss in the Education section, income is directly proportional to the level of education attained. But traditionally, where have the high school graduates (or less) gone for work?: The mill, the factory, the plant, or the mine. Those jobs are gone and as we showed in the section on Demographics, a large percentage of people are out of the labor force or on some type of welfare: unemployment or disability.

Gross Private Domestic Investment of the GDP includes Fixed investment and Residential investment. In the former is business investment, which would include manufacturing and other nontradable industries. In 1990, business investment as a per cent of GDP was about 11\% dropping to below $10 \%$ by 2010 . The economist John Taylor has shown an inverse correlation between business investment and unemployment.(Taylor) 
And it is worth noting that Gross Private Domestic Investment (GPDI):

\begin{tabular}{lcc}
\hline & Year & GPDI as a \% of GDP \\
\hline 1999 & & 18.7 \\
$2009(\mathrm{QIII})$ & 12.5 \\
2014 & & 17.0 \\
\hline
\end{tabular}

It is still less than when the LFPR began its decline. Much of corporate America has been investing overseas.

The final concept in America's loss of nontradable employment results from both our trade policies and corporate taxes. In the former: There is a big difference between GE's putting up a turbine plant to serve the Asian market, and Silicon valley companies developing products here, and manufacturing them off shore, and then importing them back to America. As far back as 2010, there were about 168,000 employed in manufacturing in the computer industry in America; at that time, Foxconn, a contract manufacturer had over 1.5 million workers, many in unhealthy working conditions in Asia. The American importer now could avoid our labor and environmental laws. The labor savings, of Asian made goods, pale in comparison to the external costs that U.S. companies can avoid. 14 people committed suicide in a Foxconn plant in China; many deaths in apparel plants in Bangladesh have been reported, Those American companies face only social pressures.

In terms of taxes, corporate taxes in the U.S. are the highest among all OECD countries. American companies deduct taxes paid in host countries, paying no cash taxes on these profits until repatriated. Worse, by leaving trillions of dollars overseas, those funds are available for more off-shoe plant expansion. The cycle continues, as does the decline in the LFPR

Finally, Spence and Gerard seem to agree on the need for an industrial policy for America. In reality, we already have a de facto industrial policy: One that favors the multinational corporation over small business which is the engine of job creation. It is one that resembles "crony capitalism" with some industries gaining favorable tax treatment, such as the pharmaceutical industry expensing R\&D, while other manufacturers must use arcane depreciation rules. There are clear winners and losers in the present corporate tax structure.

Spence uses modern Germany as he formulates a new industrial policy. Beginning in about 2000, "Germany ... has managed to retain its advanced manufacturing activities in industrial machinery by removing rigidities in the labor market and making a conscious effort to privilege employment over rapid rises in incomes. Wages may have increased only modestly in Germany over the past decade, but income equality is markedly flatter than in the United States, where it is higher than in most other industrial countries and rising steadily. ...For example, the ratio of the average income of the top $20 \%$ of the population to the bottom $20 \%$ is four to one on Germany and eight to one in the U.S." (Spence) A change in the personal tax code is also in order; again certain behavior is reinforced by the code - activities that may not advance our economic interests. And, as we will discuss in the Education section, apprenticeship is one clear answer to maintain and develop the tradable sector and reduce youth unemployment and increase that cohort's LFPR.

Spence suggests the following changes in our Industrial Policy by our government: funding R\&D and infrastructure "with the specific goal of restoring competitiveness and expanding employment in the tradable sector". (Spence) Lower corporate tax rate structures should favor on shore investing and the repatriation of funds for that purpose. Government funding for education should clearly favor STEM, where a return is demonstrable. .The corporate tax code should reflect policies that will increase employment and increase the LFPR. We have a corporate tax code now that each end of the political spectrum sees as either "crony capitalism" of lobbying by special interest groups.

Tyler Cowan makes the same case for policy changes, which he refers to as a "reset". He also refers to the German example of necessary and effective policy changes. (Cowan) 


\section{CONCLUSION}

Some of the sections have had economists that have conducted statistical studies to measure some of the structural variables to account for the decline of the LFPR. Aronson et al. have taken great pains to examine the respective cohorts to be able to conclude that a $2 \frac{1}{2} \%$ decline in the LFPR over the next decade will come from demographics. They and Robert Hall take a close look at the rise in disability insurance (SDDI) from which there is little return to the labor force. Hall has written definitively on the effects of welfare on the LFPR. But quantifying the effects of the various structural forces on the LFPR is difficult. The studies on education point to the decline in the LFPR of the education segments. And finally, Michael Spence has written the definitive study of globalization and the declining job prospects as its results.

The problem here is that the above forces/contributors to the decline of the LFPR all interact. If there are no meaningful semi-skilled jobs for high school graduates, education will not provide upward mobility, and only dead end service jobs remain, further polarizing America's incomes. If a welfare recipient is financially "penalized" for living with a working partner, why would not that person drop or stay out of the labor force? Closer to the point, demographic and educational studies are fine, but if they run counter to welfare reinforcement schedules that make a transition back to the labor force illogical, their information value is diminished. And finally if there are just no jobs available for those with limited educational background and levels (and America will always have an underclass; it's part of our century long immigration policy) why should entering the labor force make sense?

Spence and Cowen allude to the post-industrial society that we have created, through fiscal and trade policies. Those not participating in the labor force become the underclass. If the decline in the LFPR persists, it will exacerbate the polarization of incomes reflective of America, without the positive effects of economic growth. At that point redistribution will become a rallying cry. Then perhaps we will realize that a wholesale change in our industrial policy, and changes in our welfare programs, and reform in personal and corporate tax policies, may well be not only necessary to ameliorate the polarization of incomes in America, but also will reverse the decline in the LFPR as well.

\section{AUTHOR INFORMATION}

Mr. Dunn is currently an Adjunct Faculty member of the Economics and Legal Studies Department of Robert Morris University. He is also President of J.H. Dunn and Company, which provides strategic and financial advisory services to middle market corporate clients. Recent assignments have included advising the shareholders on a divestiture, two corporate sales, six acquisitions including negotiations and valuations, and an independent valuation of a private company to evaluate strategic alternatives. He has served on several corporate boards, including a Houston based container manufacturing company; a Pittsburgh based manufacturer of refractory products; and on the advisory boards of a manufacturer of titanium products and an early stage enterprise serving the energy industry. Prior to establishing his company, Mr. Dunn was a Managing Director of PNC Capital Markets for ten years, actively involved in the Mergers \& Acquisitions for the corporate clients of PNC Financial Services Group. Prior to PNC, Mr. Dunn spent most of his career with commercial and investment banks, including Citigroup and before that, with the CIT Group. Since 2011, he has been a member of the Pittsburgh Business Advisory Council of the Pittsburgh Branch of the Federal Reserve Bank of Cleveland. Mr. Dunn holds an AB Degree from Princeton University and an MBA from the University of South Carolina. E-mail: dunnj@rmu.edu

Professor Litzinger is a faculty member at Robert Morris University. He teaches undergraduate and graduate courses in economics. He was a founder and co-director of The Leonard M. Kokkila Center for Economic Education at Robert Morris University and an original organizer and co-director of a nationally recognized conference on teaching economics held annually at Robert Morris University since 1990. He regularly makes presentations at academic conferences and meetings and is the author, or coauthor, of a number of articles and book reviews in the field of economics. He holds membership in a number of professional associations and is a past president of the Pennsylvania Economic Association. He is a member of the Board of Trustees, Sewickley Savings Bank. He is a founder and current member of the Military Affairs Council of Western Pennsylvania. He is a past president of the Airport Area Development Council and of the Western Pennsylvania Coalition for Military Presence and Job Retention. He was inducted into Phi Beta Kappa and earned a Bachelor of Arts in Political Science, a 
Master of Arts in Economics, and a Doctor of Philosophy in Economics at the University of Pittsburgh. E-mail: litzinger@rmu.edu

\section{REFERENCES}

Alexander, Gary D. Secretary of Public Welfare, Commonwealth of Pennsylvania,(2007) Statement Before the Senate Budget Committee, United States Senate, February 13.

Aronson, Stephanie, Thomas Cajner, Bruce Fallick, Felix Galber-Reig, Christopher L. Smith, and William Wascher (2004) "Labor Force Participation : Recent Developments and Future Prospects" Finance and Economic Discussion Series Division of Research \& Statistics and Monetary Affaires, Federal Reserve Board, Washington, $D, C$.

Autor, David H. (2011) "The Unsustainable Rise of the Disability Rolls in the United States: Causes, Consequences, and Policy Options." November 23.

Basel, Wesley and Brett O'Hara, (2005) Incorporating EITC Participating Data into the SAIPE Program's County Poverty Model." U.S. Census Bureau, Small Area Estimates Branch, January 1.

Bauman, Kurt J. () "The effect of Work and Welfare on Living Conditions and Single Parent Households", Population Division, U.S. Bureau of the Census. August

BLS Education Economic News Release (2005) "Table A-4 Employment Status of the Civilian Population 25 Years and over by Educational Attainment" July 2

BEA, Bureau of Economic Analysis (2015) "Labor Force Statistics From the Current Population Survey" August 10.

BEA GDP 1977-2014: "Manufacturing, Textiles and Apparel", (2015)

BLS Monthly Labor Review (2013) "Labor Force Projections to 2022: The Labor Force Participation Rate Continues to Fall" December

Bureau of Labor Force Statistics (2015) “Job Openings and Labor Force Turnover Survey (JOLTS) Highlight”, June

Boselovic, Les, "Len Boselovic's Heard Off the Street: Same Old Song on Imports, Health of the U.S. Steel Producers, Pittsburgh Post-Gazette, July 26.

Cowan, Tyler (2015) “Don’t Be So Sure the Economy Will Return to Normal” NY Times .May 15.

Dunn, John H. Jr. (2012) “The Decline of Manufacturing in the United States and Its Impact on Income Inequality”, The Journal of Applied Business 011) Research, September/October

Erceg, Christopher J. and Andrew T. Levin (2013) "Labor Force Participation and Monetary Policy in the Wake of the Great Recession" IMF Working Paprer13/205, July 2013

Gaston, William (2014) “America's Challenge: Growth That Works For All”, Wall Street Journal, September 10.

Hall, Robert E., (2014) Quantifying the Lasting Harm to the U.S. Economy From the Financial Crisis" NBER Working Paper no.20813, May

Hotchkiss, Julie L. and Fernando Rios-Avila (2013) "Identifying Factors Behind the Decline in the labor Force Participation Rate" Business and Economic Research, Macrothink Institute, Vol. 3, No.1 pp 257-275.March 12.

Kaiser Family Foundation/New York Times/ CBS News (2014) "Non-Employed Poll”, December

Lazear, Edward P. and James P. Spietzer (2012) “ The United States Labor Market: Status Quo or a New Normal” NBER Working Paper18386, September,

Lazear, Edward P. (2012) “There is no Structural Unemployment Problerm”, Wall Street Journal September 8.

Litzinger, Patrick J. and John H. Dunn, Jr. "The labor Force Participation Rate: An Examination of the Determinants of its Recent Precipitous Decline" The Journal of Applied Business Research November/December 2013

PortalSeven.com (2015)

Schwartz, Nelson D (2015) A New Look at Apprenticeships as a Path to the Middle Class" New York Times, July 13.

Sherk, James (2012) "Not looking For Work: Why Labor Force Participation Has Fallen During the Recovery" The Heritage Foundation Backgrounder August 30.

Shierholz, Heidi (2012) "Labor force participation skewing unemployment numbers" Economic Policy Institute, March 21.

Skinner, B.F. (1959) "Science and Human Behavior", The Macmillan Company

Spence, Michael (2011) "Globalization and Unemployment" Foreign Affairs, July, August 20111ssue

Spreen, Thomas Luke (2013) "Recent College Graduates in the U.S. Labor Force: Data from the Current Population Survey", Monthly Labor Review, February

Taylor, John B. (2011) "Investment and Unemployment: A Reply”. Economics One, a Blog by John B. Taylor March 31. War on Poverty Wikipedia (2015) http://www.census.gov//hhes/ www./poverty/data/historical/people.html and Payne, James L. (1999) "Why The War on Poverty Failed" Foundation for Economic Education, January 01. 